\title{
Promoting Green Behavioral Intentions of the Tourists for the Growth of Sustainable Tourism Development in the Sundarbans of Bangladesh
}

\author{
Kajol Karmoker ${ }^{1} \&$ Feroz Ahmed ${ }^{2}$ \\ ${ }^{1}$ Human Resource Management Discipline, Khulna University, Bangladesh \\ ${ }^{2}$ Business Administration Discipline, Khulna University, Bangladesh \\ Correspondence: Kajol Karmoker, Human Resource Management Discipline, Khulna University, Khulna 9208, \\ Bangladesh, E-mail: Kajol.bad@gmail.com or Kajol.hrm@ku.ac.bd
}

Received: July 13, 2021

doi:10.5539/ijbm.v17n1p52
Accepted: November 17, 2021

Online Published: December 14, 2021

\begin{abstract}
The Sundarbans, the single largest mangrove forest of the world is one of the prime tourism destinations of Bangladesh. Due to lack of awareness and proper planning, tourism is causing severe threat to the ecosystem of the Sundarbans. It is therefore utmost important to ensure that the natural environment of the Sundarbans doesn't deteriorate further. Promoting green tourism may be a viable way to achieve it. This study was designed to identify the ways to promote green (environment-friendly) behavior among the stakeholders, especially the tourists traveling into the Sundarbans. A convenience sampling technique was used in the study that included both domestic and foreign tourists. A structured questionnaire was developed that incorporated 30 Likert-scale questions based on four variables, namely 'awareness program', 'incentive programs', 'interpretation' and 'government interventions'. The four variables and their corresponding items were developed in the light of extant literature and adopted based on the socio-cultural atmosphere of Bangladesh. The survey was conducted from October 2019 to February 2020 and 320 valid responses were obtained. Multiple regression analysis was employed to test the proposed research model. The result shows that out of four independent variables, government intervention and incentive programs are significantly influential factors in achieving the green behavior of the tourists. The study findings are aligned with the previous studies. The findings will provide guidelines to the tourism service providers, destination hosts, local communities, government bodies and policy makers in achieving green behavior of the tourists that in turn will yield sustainable tourism in the Sundarbans.
\end{abstract}

Keywords: Sundarbans, Tourists, green behavior, government intervention, incentive programs

\section{Introduction}

The Sundarbans ecosystem-the UNESCO declared world heritage site is a fragile tourism destination of Bangladesh (Chowdhury \& Akber, 2015). Unplanned tourism development is one of the major reasons for natural degradation to this tourism destination. Muhammed et al. (2008) report that forest areas in Bangladesh are deteriorating at an alarming rate due to various socio-economic threats such as biotic pressures and competing uses for the land. Lack of motivation and awareness among the local people, absence of appropriate information, and lack of proper guidelines for the tourists are major reasons for the destination's degradation (Ahsan, 2008). Adopting the ecotourism concept can help to eliminate many of these problems. Researchers argue that ecotourism may be a means of alleviating environmental and socio-economic issues and a tool for sustainable development in ecologically sensitive areas (Kiper \& Saglam, 2011). Ecotourists are different from any other type of tourist (Palacio, 1997). The tourists who have stronger environmental concerns than others have been described as green tourists or ecotourists (Seers \& Mair, 2009), and green tourists are more likely to engage in green behaviors than those who are indifferent toward the natural environment (Leonidou et al., 2014). Mair \& Laing (2013) argue that people who select ecotourism often have a higher awareness about the destination. This type of behavior is also labeled as 'eco-friendly behavior', 'conservation behavior', 'pro-environmental behavior', 'environmental responsible behavior', or 'environment friendly behavior' (Wang et al., 2018). All the words encompass a common behavior; behavior that protects the environment, reduces negative impacts on the ecosystem, and ensures sustainability for the future generation (Joseph, 2019; Steg \& Vlek, 2009). However, to develop ecotourism or sustainable tourism, the stakeholders, including tourists, local people, tourism service providers, and government organizations, need proper education. If the stakeholders of tourism, especially the tourists, demonstrate green 
behavioral attitudes, it may reduce the risk of natural degradation of the destination. Green behavior of the tourists denotes all types of tourist activities that intentionally reduce negative impacts but maximize positive effects on the natural environment and destination community (Steg \& Vlek, 2009).

The green behavior of the tourists may enhance the attractiveness of the destination. Lita et al. (2014) shows that tourism service providers' attitudes toward green behavior also positively impacted the overall image of the destination that yield positive impacts on the intention to visit, word-of-mouth, and willingness to pay more. A study in Europe and North America shows that consumers are more likely to patronize and demonstrate a strong desire to pay for hotels practicing environmentally friendly practices. However, Witherspoon (1994) argues that around one half of those who claimed to have green values do not perform accordingly. Witherspoon adds that very few consumers show a consistent environmentally friendly attitude. In Bangladesh, a majority of the tourists, especially the domestic tourists, lack sufficient knowledge of the expected behavior or green behavior. But, the green behavior of the stakeholders, especially the tourists' green behavior is essential for the survival of the Sundarbans. Without the proper initiatives of promoting green behavior among tourists, the existence of the Sundarbans will be in jeopardy. Thus, the current study designed to explore the ways to promoting the green behavioral intentions of the tourists in the Sundarbans of Bangladesh.

\section{Conceptual Background}

\subsection{Tourist Green Behavior}

Key elements of green tourist behavior are green consumption, supportive environmental policy, environmental persuasion, and protecting the wildlife and habitat conservation (Larson et al., 2015). Wang et al. (2018), in the context of B\&B operations in China, define green behavior of the tourist as conservation lifestyle actions (e.g. recycling plastic and paper, reusing linen and towels, conserving energy, and water) and social environmentalism (e.g. respecting local customs, environmental values, and participating in local environmental activity). In this study, tourist's green behavior means avoiding those activities that maximize negative impact on the Sundarbans, such as disturbing the wild animals, making noise, taking photography using a flashlight at night, lightening the campfire, violating the rules and regulations, littering, wearing any unacceptable dress or drinking alcohol in public.

\subsection{Sustainable Tourism}

It is highly argued that tourist green behavior is the only way to achieve sustainable tourism development (Miller et Al., 2010). According to the World Tourism Organization (WTO, 1989), "sustainable tourism development meets the needs of present tourists and host regions while protecting and enhancing opportunities for the future". It is envisaged as leading to the management of all resources so that economic, social, and aesthetic needs can be fulfilled while maintaining cultural integrity, essential ecological processes, and biological diversity. Several authors (e. g. Schaller et al., 2013; Tosun, 2001) define sustainable tourism as the development of tourism in a particular destination through conserving the nature and socio-cultural resources and involving the community in tourism to yield sustainable economic, environmental, and socio-cultural benefits for the people of the destination. Cater (1993) points three key objectives for sustainable tourism: meeting the short term and long term needs of the host population, satisfying the demands of a growing number of present and future tourists, and safeguarding the natural environment to achieve both of the preceding goals. Though sustainability, sustainable tourism, and sustainable development are often used interchangeably in the literature, 'sustainability' focuses on steady life conditions for the next generation to come; 'sustainable development is more process-oriented, and 'sustainable tourism' is all types of conventional and alternative forms of tourism that are compatible with or contribute to sustainable development (Liu, 2003). The World Trade Organization (WTO) Inter-Parliamentary Conference on Tourism in 1989 resulted in the Hague Declaration on Tourism also states that sustainable tourism is closely related to the sustainable development of tourism (WTO 1989).

\subsection{Factors Affecting the Tourist Green Behavior}

While investigating the causative factors of tourist green behavior, tourism scholars indicate that several factors influence the tourists' green behavior or environmentally responsible behavior. The factors are environmental education (Thapa et al., 2005), ecological knowledge (Carmi et al., 2015; Beaumont, 2001; Cottrell, 2003; Duerden \& Witt, 2010), environmental attitudes and values (Kaiser et al. 2005; Halpenny, 2010), environmental commitment (Lee 2011; Cottrell, 2003; Davis et al., 2009), destination attractiveness (Cheng et al., 2013), selfefficacy (Tabernero \& Hernandez 2011), cultural factors (Milfont et al. 2006), interpretation services (Ballantyne et al., 2011; Kim et al., 2011), satisfaction (Ramkissoon \& Mavondo, 2014), involvement (Chiu et al., 2014), and so forth. Moreover, in the context of nature-based tourism, several studies indicate that place attachment is directly or indirectly linked to tourist green behavior (Cheng et al., 2015; Ramkissoon \& Mavondo, 2014; Lee, 2011; Halpenny, 2010). Recreation experience and recreational involvement are also considered powerful predictors of 
tourists' green behavior in many studies (Ballantyne et al. 2011; Lee \& Jan, 2015; Lee et al., 2015). Additionally, Osbaldiston \& Sheldon (2003) and Andereck (2009) indicate that tourist motivation gaining from the nature-based experience is also a critical factor for predicting environmentally responsible behavior. However, studies concerning the development of strategic tools for increasing environmental knowledge, values, attitudes, commitment and fostering positive behavior among the tourists are insufficient within nature-based tourism settings like the Sundarbans. So, it's essential to develop few strategies for promoting green knowledge and behavior for the sustainable development in the Sundarbans.

\section{Hypotheses Development}

\subsection{Awareness Programs}

Environmental awareness means being aware of the natural environment and making choices that benefit the earth rather than hurt it (Fryxell \& Lo 2003). People of both developed and developing countries are becoming aware of the environmental issues due to the increased pressure of preserving the environment. Environmentally concerned people believe that the environment is under threat due to the problems caused by human actions, and this belief ultimately affects their behavioral practices and encourages them to display responsible behaviors (Joseph, 2019; Lee et al., 2012). It is argued that tourists' environmental awareness and moral responsibility can play a vital role in enhancing the likelihood of engaging in environmentally responsible behavior during travel hours (Han et al., 2016). Wurzinger \& Johansson (2006) also argue that tourists with richer environmental knowledge are more concerned about the ecological issues of visited locations. Furthermore, many travel companies are continuously trying to make the tourists environmentally concerned by opening such programs as "Go Green" (Tung, 2013). The motive of such program is not only to enhance environmental awareness but also to inspire the tourists to be engaged in green behavioral practices for the sake of sustainable development in the tourism sector (Tung, 2013), since tourists' environmental responsible behavior help minimize destruction to the natural ecosystem (Chiu et al., 2014).

To increase the environmental awareness among the tourists, Bangladesh Forest Department (2015) has also taken few initiatives. Some of those are providing travel instructions regarding what to do and what not to do in a specific site, distributing booklets, brochures or guidebooks containing the rules and regulations for traveling in the Sundarbans, and providing a route map directing viewable areas of the Sundarbans. Providing brochures, booklets, touch screens or guide books to make the tourists aware of their green behavior is also evidenced in the study of Wang et al. (2018), in which they show that suggested instructions influence the tourists' behavior. The use of environmental signage around the tourist spots is also been proposed as a powerful mechanism for shaping tourists' green behavior (Walker \& Moscardo, 2014; Wang et al., 2018). Furthermore, environmental awareness-raising programs like essay competition, debate, radio quizzes, tourism awareness week, tourism action clubs, TV programs, and tourism awareness competitions can raise awareness regarding environmental cleanliness, safety, and security (Gray et al., 2005). Likewise, Furqan et al. (2010) claim that promoting green behavior or developing environmentally responsible behavior among the tourists can be enhanced by such programs as environmental seminars, campaigns, and involvement in outdoor activities or hobbies.

Consequently, the awareness-raising programs focusing on good manners in the environment can directly or indirectly encourage the tourist to be engaged in green behavioral practices (Pearce, 2005), because once the tourists are aware of the responsible behaviors towards the environment, they are expected not to litter during the tour, not to disturb the wild animals, not to fire, not to damage the vegetation, and so forth (Chiu et al., 2014). Sometimes people's environmental awareness influences their willingness to participate in green behavior as a tourist (18). Because the ecological awareness of the tourists restricts the irresponsible behavior towards the environment at the tourist destination, thus, we can hypothesize that:

\section{H1: Tourism awareness programs can positively promote tourists' green behavioral intentions.}

\subsection{Incentive Programs}

Incentivizing has also been found to be one factor that inspires tourists to participate in pro-environmental actions (Line et al., 2017). Incentive programs can encourage the tourists to be engaged in environmentally friendly behavior during their travel time on vacation (Miao \& Wei, 2013). Many hotels and other lodging establishments sometimes offer discounts on the purchase of green foods and beverages or offer coupons for using environmentfriendly products or give loyalty points relieved from monetary value (Barber, 2014). Jiang \& Kim (2015) argue that consumers with a promotion regulatory fit actively pursue environmental protection if they find themselves in the condition of the cash discount incentive. This argument is further enhanced as Chang et al. (2019) show that consumers with a prevention regulatory fit are induced to have more excellent behavioral intentions toward the hotel, suggesting a cash discount to implement its green marketing practices. Cash discounts on green products 
can change the attitude of green consumers and thereby motivate them to protect the environment (Lanzini \& Thøgersen, 2014; Krakovsky, 2008). Even the cash discount is found as a moderating variable to moderate the relationship between environmental awareness and green consumer behaviors (Huang et al., 2014). So, it can be argued that the financial incentives in the form of cash discounts or coupons can directly or indirectly encourage many tourists to display pro-environmental behavior.

Furthermore, motivational incentives that include intrinsic or extrinsic motives can also influence the proenvironmental behavioral intentions of the tourists (Frey \& Jegen, 2001). Intrinsic motives comprise of moral values and a sense of obligation of a person. For instance, a tourist might think that it is not morally right to pollute the environment, indicating that a sense of commitment to protecting the environment for the future generation works due to a tourist's intrinsic motives. On the other hand, extrinsic motivations are tied to money, power and status. For instance, tourists may be motivated towards green practices if they are provided with 'green tourist' status (Frey \& Jegen, 2001). So, in addition to the financial benefits, non-financial benefits like praise, complements, public recognition, social status, and power can reinforce pro-environmental behavior in many ways (Heyman \& Ariely, 2004). Griskevicius et al. (2010) show that many tourists display green behavior by choosing a relatively costly green product. They tend to pay more for green products and services to increase their social status among their peers (Seers \& Mair, 2009). Therefore, tourists are sometimes motivated towards proenvironmental behavior by non-monetary rewards rather than monetary rewards (Rajapaksa et al., 2019). Thus, we can hypothesize that:

\section{H2: Providing incentives can positively influence tourists' green behavioral intentions.}

\subsection{Interpretation}

It is now highly recognized that interpretation is a powerful mechanism in shaping tourists' green behavior (Clarke, 1997; Walker \& Moscardo, 2014). Interpretation can be defined as a means of communicating ideas and feelings, which in turn help people understand more about themselves and their environment (Interpretation Australia, 2011). In the tourism context, it is described as direct communication or personal contact with the tour guides (McKercher \& Robbins, 1997). Interpretation of tour guides plays a significant role in changing the tourist awareness, knowledge, attitudes, and behaviors towards the environment (Ballantyne et al., 2011) since it is assumed that many people gather knowledge, beliefs and form attitudes through social interaction or experiences irrespective of formal education (Walker \& Moscardo, 2014). Furthermore, a tour guide's explanation about the plants, animals, birds and their living pattern in an area (e.g., mangrove forest) can encourage the tourists to demonstrate environment-friendly behavior (Alazaizeh et al., 2019). Even after being entertained by the local jokes told by the tour guides, the tourists are more likely to respond to the local cultures and abide by local rules and regulations (Wang et al., 2018). So, it is assumed the tourists behave more responsibly on a particular site with the presence of a tour guide (Fung \& Jim, 2015).

It has been found that if a tour guide is ecologically aware of and knows better how to dispose of wastes or litter properly, they can encourage tourists to collect the leftover, keep it until the end of the tour or put it in the proper places since waste materials are a burden to the environment (Salam et al., 2000). Tourists' intention of sustainable actions can further be extended through their connection with the interpretive staff (Walker \& Moscardo, 2014). Tilden (2009) proposes that interpretation can be an effective tool to connect the interpretive experience to the visitor's personal life and stimulating a response among the visitors rather than merely presenting the information. Thus, interpretation in the form of interpretive experiences can allow tourists to gather knowledge from the interpreter as it influences the tourists' engagement and their understanding, cognitions, emotions, and on-site behaviors (Biran et al., 2011). Consequently, interpretation can be one of the best ways to promote or encourage environmentally positive attitudes, beliefs or actions or manage tourists' on-site behavior (Moscardo \& Ballantyne, 2008). Thus, we can hypothesize that:

\section{H3: The tour guide's interpretation can positively promote tourists' green behavioral intentions.}

\subsection{Government Intervention}

Recently, governments of developing countries are more active in destination management and development in the tourism sectors (Kubickova, 2016). Governments of these countries, which are actually endowed with natural attractions, have introduced few environmental policies to protect and ensure the environment's biodiversity since ecotourism is a source of their revenue generator (Ayob et al., 2009). But government intervention is essential once it is found that some people are indifferent towards the rules and regulations designed to maximize the social benefits and welfare (Hall, 2006; Wolf, 1993). Such intervention compels the tourists to behave responsibly. For instance, in Kenya, tourists are not allowed to take photographs of local people or their homes and livestock without the owner's consent. Fireworks, night drive, talking louder or carrying speaker whistles are strictly 
prohibited in their forests. It is barred to chop, cut or damage the trees of the forests. Getting too close to the animals or feeding them is also forbidden because sometimes this type of incident may be dangerous to tourists. Even the tourists have to carry their drinking water, and they are not allowed to throw it here and there in the forests (Gray et al., 2005). Bangladesh Forest Department (2015) tries to regulate and control the Sundarbans' tourism to ensure eco-friendly behavior. As part of that control, travelers in the Sundarbans need to maintain the conventional forest and wildlife protection law. Landing, roaming, and footing here and there in the forest are not granted. After entering the Sundarbans, it is highly forbidden to throw garbage into water and ground. Keeping the vessel neat and clean is a must. It is highly prohibited to take pictures by using a flashlight at night.

Therefore, the government can impose laws and regulations to ensure sustainable practices in the tourists' spots (Lin \& Hemmington, 1997). A clear indication of government-industry cooperation to promote sustainable tourism is also found in the study of Maycoo (2006). According to Maycoo (2006), the government can directly or indirectly influence sustainable tourism practices through regulatory mechanisms and market instruments, whereas the industry can play the role of voluntary compliance with green certification. Delivering information, education, training, and a green rating system can inspire the tourism industry and introduce environmentally responsible practices (Bramwell, 1998). Moreover, the government's financial incentives in the form of subsidies or tax reduction can be introduced to encourage environmentally responsible behaviors. Besides, the tour operators or other concerned body can be changed due to environmentally or culturally damaging practices (Hunter \& Green, 1995). Thus, we can hypothesize that:

\section{H4: Government intervention can influence tourists' green behavioral intentions.}

Hence, this study drawn four hypotheses based on extent literature and designed to investigate whether awarenessraising programs, incentive programs, tour guide's interpretation, and government intervention can positively influence the green behavioral intentions of the tourists. Based on the drawn hypotheses a research model of this study is designed that is shown in Figure 1.

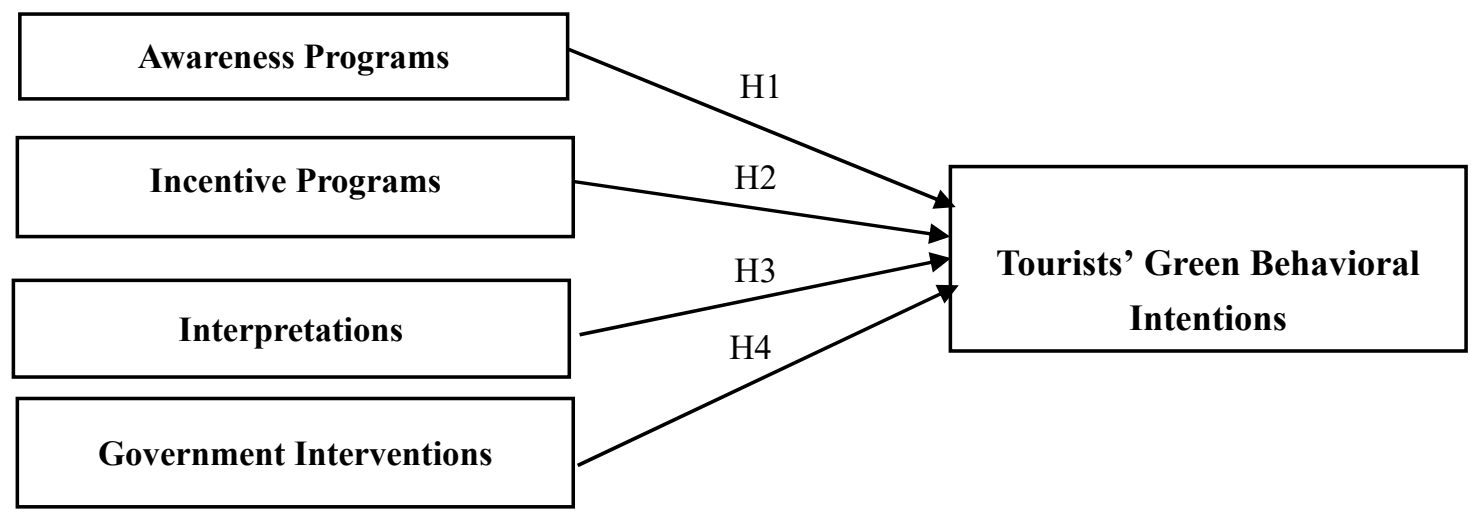

Figure 1. Research model

\section{Methodology}

\subsection{Sampling}

A convenience sampling technique was adopted in this study. A survey was conducted on domestic and international tourists - visiting the Sundarbans and finally 320 valid responses were obtained. Domestic tourists were chosen from Khulna, Shatkhira, Bagerhat, and Mongla regions of Bangladesh. International tourists were approached at the residential hotels of Khulna City, Bangladesh. The 320 sample size was adequate according to the formula: $\mathrm{N}>50+8 \mathrm{~m}$ (where $\mathrm{m}=$ number of questions of independent variables) developed by Tabachnick \& Fidell (2001 since the number of questions of the independent variables used in the study was 26 . Table 1 represents data on the demographics of the respondents. From the table, it can be seen that among the 320 respondents, $80.3 \%$ (257) were domestic, and 19.7\% (63) were international tourists. In terms of gender, $70 \%$ (224) were male, and $30 \%$ (96) were female tourists. The tourists were of different ages and different occupations. 
Table 1. Demographic Characteristics of the Respondents $(\mathrm{N}=320)$

\begin{tabular}{|c|c|c|c|}
\hline Characteristics & Classification & Frequency & Percentage \\
\hline \multirow[t]{2}{*}{ Gender } & Male & 224 & 70 \\
\hline & Female & 96 & 30 \\
\hline \multirow[t]{4}{*}{ Age } & $21-30$ & 184 & 57.5 \\
\hline & $31-40$ & 70 & 21.9 \\
\hline & $41-50$ & 40 & 12.5 \\
\hline & Above 50 & 26 & 8.1 \\
\hline \multirow[t]{4}{*}{ Occupation } & Service & 140 & 43.8 \\
\hline & Business & 57 & 17.8 \\
\hline & Student & 100 & 31.2 \\
\hline & Housewife & 23 & 7.2 \\
\hline Frequency of visit in the & Once & 148 & 46.2 \\
\hline \multirow[t]{2}{*}{ Sundarbans } & Twice & 77 & 24.1 \\
\hline & More than twice & 95 & 29.7 \\
\hline \multirow[t]{2}{*}{ Type of the Tourists } & Domestic & 257 & 80.3 \\
\hline & International & 63 & 19.7 \\
\hline
\end{tabular}

\subsection{Questionnaire Design and Data Collection}

A self-administered questionnaire survey was conducted from October 2019 to February 2020. The questionnaire was developed based on the outcomes of previously published works. It was then pretested and refined; some words were changed to improve the accuracy of language, clarity of the items, and relevance to the real-life practices in the Sundarbans. The questionnaire contained section A and section B. Section A was designed with 30 questions based on the dependent and independent variables. Green behavior promotional tools like awareness programs, incentive programs, interpretations, and government interventions were the independent variables, and tourists' green behavioral intention was the dependent variable. Respondents' views over the 30 questions were measured using 5-point Likert scales, where the lowest score was 1 (strongly disagree) and the highest score was 5 (strongly agree). Section B of the questionnaire was designed with eight closed-ended questions about demographic profile of the respondents. A total of 400 questionnaires were distributed among the tourists. Out of 400 questionnaires distributed, 376 were returned, of which 320 were found flawless and used in the data analysis process. SPSS version 16.0 was used to analyze the survey data.

\subsection{Measurement}

Awareness programs were assessed according to the guidance of Wang et al. (2018); Lee (2011); Bangladesh Forest Department (2015); Walker \& Moscardo (2014). A six-item index was used to measure the awareness programs and a sample item scale included "Providing booklets, brochures or guide books containing the rules and regulations can turn the tourists' behavior into green". A five-item index measured incentive programs and all the items were developed based on the understanding of Line et al. (2017); Barber (2014); Cheng et al. (2013); Heyman \& Ariely (2004). A typical scale item of measuring incentive programs was "Offering discounts on the purchase of green foods or beverages can motivate the tourists towards green consumption or behavior in the Sundarbans". Next, interpretation was measured by a five-item scale developed based on the understanding of Walker \& Moscardo (2014); Pearce (2005); Wang et al. (2018). An example scale item of interpretation was "Tour guide's instructions while walking in the Sundarbans can motivate the tourists towards green behavior". Government intervention was conceptualized using a ten-item scale, which were developed based on the guidance of Bramwell \& Alletorp (2001); Gray et al. (2005); Maycoo (2006); Bangladesh Forest Department (2015). A typical scale item of government intervention was "Restricting the tourists from feeding the wild animals can switch them towards green behavior". Finally, the dependent variable, tourists' green behavioral intention, was measured by asking them to express their opinions on the aforementioned independent variables.

\section{Data Analysis and Findings}

\subsection{Descriptive Statistics}

Table 2 displays the mean, standard deviation, and inter-correlations of all the key variables used in the study. As shown in the table, the results indicate that there is no multicollinearity among the independent variables (awareness programs, incentive programs, interpretations, and government interventions) since all the values are 
less than 0.8 (Senaviratna \& Cooray, 2019). Hence, the data was valid for regression analysis. Table 2 also presents that all the independent variables are positively correlated with the dependent variable (tourists green behavioral intentions). Most significant correlation was found between government interventions and tourists green behavioral intentions $\left(r=0.458^{* *}\right)$ followed by the incentive programs $\left(r=0.347^{* *}\right)$, interpretations $\left(r=0.268^{* *}\right)$, and awareness programs $\left(r=0.266^{* *}\right)$. These results prove a considerable influence of awareness programs, incentive programs, interpretations, and government interventions on tourists green behavioral intentions in the Sundarbans.

Table 2. Mean, SD and correlation between the measured variables

\begin{tabular}{|c|c|c|c|c|c|c|c|c|}
\hline Variables Entered & & $\mathbf{M}$ & SD & 1 & 2 & 3 & 4 & 5 \\
\hline 1. Awareness Programs & & 3.917 & 0.584 & 1 & & & & \\
\hline 2. Incentive Programs & & 3.990 & 0.641 & $0.307^{* *}$ & 1 & & & \\
\hline 3. Interpretations & & 4.110 & 0.546 & $0.135^{*}$ & $0.259^{* *}$ & 1 & & \\
\hline 4. Government Interventions & & 4.178 & 0.536 & $0.322^{* *}$ & $0.345^{* *}$ & $0.347^{* *}$ & 1 & \\
\hline 5.Tourists Green Behavioral & Intentions & 4.249 & 0.534 & $0.266^{* *}$ & $0.347^{* *}$ & $0.268^{* *}$ & $0.458^{* *}$ & 1 \\
\hline
\end{tabular}

**Correlation is significant at the 0.01 level (2-tailed). *Correlation is significant at the 0.05 level (2-tailed).

\subsection{Hypotheses Testing}

Table 3 represents the output of multiple regression analysis with which the study hypotheses were tested. Table 3 shows that $R^{2}$ value is 0.265 indicating that $26.5 \%$ variance of tourists' green behavioral intentions can be explained by the government interventions, awareness programs, interpretations, and incentive programs and the relationship among the variables is significant $(\operatorname{sig}=0.000)$. The overall model is reasonably fit with the $\mathrm{F}$ statistics of 28.367. The coefficient scores of individual variables indicate that government interventions $(\beta=0.335$, Sig. $=$ $0.000)$ and incentive programs $(\beta=0.179 \mathrm{Sig} .=0.001)$ have positive and significant contributions in explaining tourists green behavioral intentions. Thus, $H 2$ and $H 4$ are supported whereas, no support is found for $H 1$ and $H 3$. Awareness programs $(\beta=0.090$, Sig. $=0.085)$ and interpretations $(\beta=0.093$, Sig. $=0.075)$ don't make a significant contribution in explaining tourists green behavioral intentions. Consequently, based on the evidence of the study findings, it can be argued that government interventions and incentive programs can significantly influence the green behavioral intentions of the tourists in the Sundarbans.

Table 3. Regression Statistics

\begin{tabular}{|c|c|c|c|c|c|c|}
\hline Independent Variables & B & SE & $\boldsymbol{\beta}$ & $\mathbf{t}$ & $p$ & Remarks \\
\hline (Constant) & 1.559 & 0.272 & & 5.731 & 0.000 & \\
\hline Awareness Programs & 0.083 & 0.048 & 0.090 & 1.728 & 0.085 & Not supported \\
\hline Incentive Programs & 0.149 & 0.045 & 0.179 & 3.351 & $0.001^{* *}$ & Supported \\
\hline Interpretations & 0.091 & 0.051 & 0.093 & 1.789 & 0.075 & Not supported \\
\hline Government Interventions & 0.334 & 0.055 & 0.335 & 6.071 & $0.000^{* *}$ & Supported \\
\hline$R$ & $0.515^{\mathrm{a}}$ & & & & & \\
\hline$R^{2}$ & 0.265 & & & & & \\
\hline \multirow[t]{2}{*}{$F$-Statistics } & 28.367 & & & & & \\
\hline & $P<.001$ & & & & & \\
\hline $\operatorname{Adj} . R^{2}$ & 0.255 & & & & & \\
\hline$N$ & 320 & & & & & \\
\hline
\end{tabular}

Dependent Variable: Tourists Green Behavioral Intentions.

Notes: $* P<0.05 ; * * P<0.01$

\section{Result Discussion}

Green tourism is something that is essential for the sustainability of any nature-based destination and certainly the Sundarbans based tourism is no exception. From the findings, we can argue that the tourists have strong feelings that green tourism is achievable. However, several actions need to be taken in order to achieve the desired objectives. The study results confirm $\mathrm{H} 2$ and $H 4$, which are in line with the existing literature, whereas Hypotheses $H 1$ and $H 3$ were not supported by the result that contradicts many research findings. Mean values as illustrated in Table 2 also indicate that government interventions with the highest mean score of 4.17 can influence the tourists 
more to display pro-environmental behaviors in the Sundarbans compared to interpretations (4.1106), incentive programs (3.9906), and awareness programs (3.9172). Hence, it can be argued that government intervention is the most significant predictor in achieving green behavior among the tourists in the Sundarbans of Bangladesh.

In a country like Bangladesh, many tourists are not fully aware of the acceptable green behavior in the tourism destination. Moreover, a good portion of the tourists tends to violate the rule. Thus, strong government interventions will be suitable in such cases, and hence it was identified as the most practical way to achieve green behavior. This finding is in line with the outcomes of Kubickova (2016); Hall (2006); Gray et al. (2005); Maycoo (2006), in which they found that government can directly or indirectly influence sustainable tourism practices through a regulatory mechanism.

In the current study, incentive programs is found as another significant contributor in explaining tourist green behavioral intentions. This finding suggests that various incentive programs, e.g., 'offering discounts on purchase of green foods', 'offering industry sponsorship for organizing a green-focused tour' are most likely to motivate the tourists to act in favor of green behavior. This result is consistent with those of other studies (Chang et al., 2019; Line et al., 2017; Miao \& Wei, 2013; Frey \& Jegen, 2001) which conclude that both monetary and non-monetary rewards can encourage the tourists to be engaged in environmentally friendly behavior during their travel time.

In examining the relationship between awareness-raising programs and tourist green behavioral intentions, the study outcomes find no significant influence of awareness-raising programs on the tourist green behavioral intentions though it was expected to have significant impact. This finding contradicts the outcomes of many other studies, such as Lee et al. (2012) Han et al. (2016); Wurzinger \& Johansson (2006); Walker \& Moscardo (2014); Wang et al. (2018); Cheng et al. (2018). Similarly, interpretation by the tour guides is also found insignificant in promoting tourist green behavioral intentions in the current study of the Sundarbans. But, the findings of other studies (Walker \& Moscardo, 2014; Moscardo \& Ballantyne, 2008) suggest that interpretations are most likely to help people learn the desired activities in favor of green behavior. So this finding of the current study is in contrast with the findings of the said studies.

This study makes several theoretical contributions. First, the study explores the concept of tourist green behavior and its relationship with the sustainable tourism development within nature-based tourism settings like the Sundarbans. Second, the study extends the literature of the factors affecting the tourist green behavioral intentions. Third, the study investigates the impacts of awareness-raising programs, incentive programs, interpretation by the tour guides, and government interventions in promoting tourist green behavioral intentions for sustainable tourism development in the Sundarbans of Bangladesh.

\section{Practical Implications}

The findings should help the tourism stakeholders, including tourism service providers, destination hosts, local communities, government bodies, and non-governmental organizations (NGOs). This study also suggests that the tourism service providers or the destination hosts should introduce environmental awareness-raising programs, offer incentive programs, and use well-trained tour guides to promote green behavioral intentions in the Sundarbans. The study findings also strongly argue in favor of government intervention to impose rules and regulations to achieve tourists' green behavior. Tourism authorities of the government or the policymakers can use the study findings as the guidelines for policymaking purposes. Furthermore, local and international NGOs working to promote sustainable tourism can find the study result useful.

\section{Limitations and Future Research Directions}

This study was not flawless, and we found several limitations. Firstly, the study considers only the tourists' opinions. Data from other sources, such as local communities, tourism service providers, government officials, and policymakers, could be more suitable to confirm the findings' generalizability. Secondly, the study didn't show moderation or mediation effects of any variable on the association between dependent and independent variables of the study. But, the socio-demographic traits of tourists, such as gender, age, education, nationality, and income, may have moderating effects on the tourists' perception since it is found that females, older, educated, and affluent individuals are more sensitive to green issues than the others (Haarhoff, 2015). In addition, the mediation effects of tourists' satisfaction, engagement, place attachment, and commitment may be explored by the future scholars to identify the interdependencies of the study variables.

\section{Acknowledgements}

This study was funded by Khulna University Research Cell, Bangladesh. So, we convey our gratitude to Khulna University Research Cell. Besides, special thanks to the tourists who spared their valuable time and efforts while conducting the survey. 


\section{References}

Ahsan, M. N. (2008). Ecotourism in Bangladesh: a new tool for economic development. Journal of Socioeconomic Research and Development, 5(3), 299-304.

Alazaizeh, M. M., Jamaliah, M. M., Mgonja, J. T., \& Ababneh, A. (2019). Tour guide performance and sustainable visitor behavior at cultural heritage sites. Journal of Sustainable Tourism, 27(11), 1708-1724. https://doi.org/10.1080/09669582.2019.1658766

Andereck, K. L. (2009). Tourists' perceptions of environmentally responsible innovations at tourism businesses. Journal of Sustainable Tourism, 17(4), 489-499. https://doi.org/10.1080/09669580802495790

Ayob, M. Z., Saman, F. M., Hussin, Z. H., \& Jusoff, K. (2009). Tourists' satisfaction on Kilim river mangrove forest ecotourism services. International Journal of Business and Management, 4(7), 76-84. https://doi.org/10.5539/ijbm.v4n7p76

Ballantyne, R., Packer, J., \& Falk, J. (2011). Visitors' learning for environmental sustainability: Testing short and long-term impacts of wildlife tourism experiences using structural equation modelling. Tourism Management, 32, 1243-1252. https://doi.org/10.1016/j.tourman.2010.11.003

Bangladesh Forest Department (2015). Retrieved on 12 June, 2019, from http://bforest.gov.bd

Barber, N. A. (2014). Profiling the potential 'green' hotel guest: Who are they and what do they want? Journal of Hospitality \& Tourism Research, 38(3), 361-387. https://doi.org/10.1177/1096348012451462

Beaumont, N. (2001). Ecotourism and the conservation ethic: Recruiting the uninitiated or preaching to the converted? Journal of Sustainable Tourism, 9(4), 317-341. https://doi.org/10.1080/09669580108667405

Biran, A., Poria, Y., \& Oren, G. (2011). Sought experiences at (dark) heritage sites. Annals of Tourism Research, 38(3), 820-841. https://doi.org/10.1016/j.annals.2010.12.001

Bramwell, B. (1998). 21 Selecting policy instruments for sustainable tourism. Global Tourism, 361.

Bramwell, B., \& Alletorp, L. (2001). Attitudes in the Danish tourism industry to the roles of business and government in sustainable tourism. International Journal of Tourism Research, 3(2), 91-103. https://doi.org/10.1002/jtr.242

Carmi, N., Arnon, S., \& Orion, N. (2015). Transforming Environmental Knowledge into Behavior: The Mediating Role of Environmental Emotions. The Journal of Environmental Education, 46(3), 183-201. https://doi.org/10.1080/00958964.2015.1028517

Cater, E. (1993) Ecotourism in the Third World: Problems for sustainable tourism development. Tourism Management, 14(2), 85-90. https://doi.org/10.1016/0261-5177 (93)90040-R

Chang, K. C., Hsu, C. L., Hsu, Y. T., \& Chen, M. C. (2019). How green marketing, perceived motives and incentives influence behavioral intentions. Journal of Retailing and Consumer Services, 49, 336-345. https://doi.org/10.1016/j.jretconser.2019.04.012

Cheng, J., Chiang, A., Yuan, Y., \& Huang, M., (2018). Exploring Antecedents of Green Tourism Behaviors: A Case Study in Suburban Areas of Taipei, Taiwan. Sustainability, 10(6), 19-28. https://doi.org/10.3390/su10061928

Cheng, T. M., \& Wu, H. C. (2015). How do environmental knowledge, environmental sensitivity, and place attachment affect environmentally responsible behavior? An integrated approach for sustainable island tourism. Journal of Sustainable Tourism, 23(4), 557-576.

Cheng, T. M., Wu, H. C., \& Huang, L. M. (2013). The influence of place attachment on the relationship between destination attractiveness and environmentally responsible behavior for island tourism in Penghu, Taiwan. Journal of Sustainable Tourism, 21(8), 1166-1187.

Chiu, Y. H., Lee, W., \& Chen, T. (2014). Environmentally responsible behavior in ecotourism: antecedents and implications. Tourism Management, 40, 321-329. https://doi.org/10.1016/j.tourman.2013.06.013

Chowdhury, A. H., \& Akber, M. A. (2015). Study of impacts of oil spill on the Sundarbans mangrove forest of Bangladesh. Journal of the Asiatic Society of Bangladesh, Science, 41(1), 75-94. https://doi.org/10.3329/jasbs.v41i1.46193

Clarke, J. (1997). A framework of approaches to sustainable tourism. Journal of Sustainable Tourism, 5(3), 224233. https://doi.org/10.1080/09669589708667287

Cottrell, S. P. (2003). Influence of socio-demographics and environmental attitudes on general responsible 
environmental behavior among recreational boaters. Environment and Behavior, 35(3), 347-375. https://doi.org/10.1177/0013916503035003003

Davis, J. L., Green, J. D., \& Reed, A. (2009). Interdependence with the environment: Commitment, interconnectedness, and environmental behavior. Journal of Environmental Psychology, 29, 173-180. https://doi.org/10.1016/j.jenvp.2008.11.001

Duerden, M. D., \& Witt, P. A. (2010). The impact of direct and indirect experiences on the development of environmental knowledge, attitudes, and behavior. Journal of Environmental Psychology, 30, 379-392. https://doi.org/10.1016/j.jenvp.2010.03.007

Frey, B. S., \& Jegen, R. (2001). Motivational Interactions: Effects on Behavior. Annales d'Économie et de Statistique, 131-154. https://doi.org/10.2307/20076299

Fryxell, G. E., \& Lo, C. W. (2003). The influence of environmental knowledge and values on managerial behaviours on behalf of the environment: An empirical examination of managers in China. Journal of Business Ethics, 46(1), 45-69. https://doi.org/10.1023/A:1024773012398

Fung, C. K., \& Jim, C. Y. (2015). Segmentation by motivation of Hong Kong Global Geopark visitors in relation to sustainable nature-based tourism. International Journal of Sustainable Development \& World Ecology, 22(1), 76-88.

Furqan, A., Som, A. P. M., \& Hussin, R. (2010). Promoting green tourism for future sustainability. Theoretical and Empirical Researches in Urban Management, 8(17), 64-74.

Gray, L. P., Reisinger, Y., Kim, J. U., \& Thapa, B. (2005). Do US tour operators' brochures educate the tourist on culturally responsible behaviors? A case study for Kenya. Journal of Vacation Marketing, 11(3), 265-281. https://doi.org/10.1177/1356766705055719

Griskevicius, V., Tybur, J. M., \& Bergh, B. V. D. (2010). Going green to be seen: Status, reputation, and conspicuous conservation. Journal of Personality and Social Psychology, 98(3), 392-404. https://doi.org/10.1037/a0017346

Haarhoff, R. (2015). Exploring tourist's attitude towards a greener future: do we really care? African Journal of Hospitality, Tourism and Leisure, 4(1), 1-11.

Hall, J. C. (2006). Positive externalities and government involvement in education. Journal of Private Enterprise, 21(2), 165-175.

Halpenny, E. A. (2010). Pro-environmental behaviours and park visitors: The effect of place attach- ment. Journal of Environmental Psychology, 30, 409-421. https://doi.org/10.1016/j.jenvp.2010.04.006

Han, J. H., Lee, M. J., \& Hwang, Y. S. (2016). Tourists' Environmentally Responsible Behavior in Response to Climate Change and Tourist Experiences in Nature-Based Tourism. Sustainability, 8(7), 1-14. https://doi.org/10.3390/su8070644

Heyman, J., \& Ariely, D. (2004). Effort for Payment. Psychological Science, 15(11), 787-793. https://doi.org/10.1111/j.0956-7976.2004.00757.x

Huang, H. C., Lin, T. H., Lai, M. C., \& Lin, T. L. (2014). Environmental consciousness and green consumer behavior: An examination of motivation crowding effect. International Journal of Hospitality Management, 40, 139-149. https://doi.org/10.1016/j.ijhm.2014.04.006

Hunter, C., \& Green, H. (1995). Tourism and the environment: A sustainable relationship? Routledge.

Interpretation Australia. (2011). What is interpretation? Retrieved 12 June, 2019 from https://interpretationaustralia.asn.au/about-interpretation-australia/what-is-interpretation/

Jiang, Y., \& Kim, Y. (2015). Developing multi-dimensional green value: extending social exchange theory to explore consumers' purchase intention in green hotels-evidence from Korea. International Journal of Contemporary Hospitality Management, 27(2), 308-334. https://doi.org/10.1108/IJCHM-08-2013-0383

Joseph, O. O. (2019). Pro-Environmental Consumer Behavior: A Critical Review of Literature. International Journal of Business and Management, 15(1), 1-15. https://doi.org/10.5539/ijbm.v15n1p1

Kaiser, F. G., Hübner, G., \& Bogner, F. X. (2005). Contrasting the theory of planned behavior with the valuebelief-norm model in explaining conservation behavior 1. Journal of Applied Social Psychology, 35(10), 2150-2170. https://doi.org/10.1111/j.1559-1816.2005.tb02213.x

Kim, A. K., Airey, D., \& Szivas, E. (2011). The multiple assessment of interpretation effectiveness: Promoting 
visitors' environmental attitudes and behavior. Journal of Travel Research, 50(3), 321-334. https://doi.org/10.1177/0047287510362786

Kiper, T., \& SAĞLAM, C. (2011). Environmental, socio-cultural and economic effects of ecotourism perceived by the local people in the northwestern Turkey: Kiyiky case. Scientific research and Essays, 6(19), 40094020. https://doi.org/10.5897/SRE10.1059

Krakovsky, M. (2008). Less wash, more dry: For hotel towel reuse, social pressure beats green values. Scientific American, 299(5), 28-29. https://doi.org/10.1038/scientificamerican1108-28

Kubickova, M. (2016). The role of government in tourism: linking competitiveness, freedom, and developing economies. Czech Journal of Tourism, 5(2), 73-92. https://doi.org/10.1515/cjot-2016-0005

Lanzini, P., \& Thøgersen, J., (2014). Behavioral spillover in the environmental domain: an intervention study. Journal of Environmental Psychology, 40, 381-390. https://doi.org/10.1016/j.jenvp.2014.09.006

Larson, L. R., Stedman, R. C., Cooper, C. B., \& Decker, D. J. (2015). Understanding the multi-dimensional structure of pro-environmental behavior. Journal of Environmental Psychology, 43, 112-124. https://doi.org/10.1016/j.jenvp.2015.06.004

Lee, T. H. (2011). How recreation involvement, place attachment, conservation commitment affect environmentally responsible behavior. Journal of Sustainable Tourism, 19(7), 895-915. https://doi.org/10.1080/09669582.2011.570345

Lee, T. H., \& Jan, F. H. (2015). The effects of recreation experience, environmental attitude, and biospheric value on the environmentally responsible behavior of nature-based tourists. Environmental Management, 56, 193208. https://doi.org/10.1007/s00267-015-0488-y

Lee, T. H., Jan, F. H., \& Huang, G. W. (2015). The influence of recreation experiences on environmentally responsible behavior: The case of Liuqiu Island, Taiwan. Journal of Sustainable Tourism, 23(6), 947-967. https://doi.org/10.1080/09669582.2015.1024257

Lee, Y., Choi, J., Kim, M., Ahn, Y., \& Katz-Gerro, T. (2012). Explaining pro-environmental behaviours with environmentally relevant variables: a survey in Korea. African Journal of Business Management, 6(29), 86778690.

Leonidou, L. C., Coudounaris, D. N., Kvasova, O., \& Christodoulides, P. (2014). Tourist environmental attitude and behavior: Antecedents, moderators, and outcomes.

Lin, Y. H., \& Hemmington, N. (1997). The impact of environmental policy on the tourism in Taiwan. Progress in Tourism and Hospitality Research, 3(1), 35-45.

Line, N., Hanks, L., \& Miao, L. (2017). Image Matters: Incentivizing Green Tourism Behavior. Journal of Travel Research, 57(3), 296-309. https://doi.org/10.1177/0047287517697848

Lita, R. P., Surya, S., Ma'Ruf, M., \& Syahrul, L. (2014). Green attitude and behavior of local tourists towards hotels and restaurants in West Sumatra, Indonesia. Procedia Environmental Sciences, 20, 261-270. https://doi.org/10.1016/j.proenv.2014.03.033

Liu, Z. (2003). Sustainable tourism development: A critique. Journal of Sustainable Tourism, 11(6), 459-475. https://doi.org/10.1080/09669580308667216

Mair, J., \& Laing, J. H. (2013). Encouraging pro-environmental behavior: the role of sustainability-focused events. Journal of Sustainable Tourism, 2(8), 1113-1128.

McKercher, B., \& Robbins, B. (1997). Developing successful Nature-based Tourism Businesses.

Miao, L., \& Wei, W. (2013). Consumers' pro-environmental behavior and the underlying motivations: A comparison between household and hotel settings. International Journal of Hospitality Management, 32, 102112. https://doi.org/10.1016/j.ijhm.2012.04.008

Milfont, T. L., Duckitt, J., \& Cameron, L. D. (2006). A cross-cultural study of environmental motive concerns and their implications for proenvironmental behavior. Environment and Behavior, 38(6), 745-767. https://doi.org/10.1177/0013916505285933

Miller, G., Rathouse, K., Scarles, C., Holmes, K., \& Tribe, J. (2010). Public understanding of sustainable tourism. Annals of Tourism Research, 37(3), 627-645. https://doi.org/10.1016/j.annals.2009.12.002

Moscardo, G., \& Ballantyne, R. (2008). Interpretation and attractions. Managing visitor attractions: New directions, 237-252. https://doi.org/10.1016/B978-0-7506-8545-0.50022-8 
Muhammed, N., Koike, M., \& Haque, F. (2008). Forest policy and sustainable forest management in Bangladesh: an analysis from national and international perspectives. New Forests, 36(2), 201-216. https://doi.org/10.1007/s11056-008-9093-8

Mycoo, M. (2006). Sustainable tourism using regulations, market mechanisms and green certification: A Case Study of Barbados. Journal of Sustainable Tourism, 14(5), 489-511. https://doi.org/10.2167/jost600.0

Osbaldiston, R., \& Sheldon, K.M. (2003). Promoting internalized motivation for environmentally responsible behavior: A prospective study of environmental goals. Journal of Environmental Psychology, 23, 349-357. https://doi.org/10.1016/S0272-4944(03)00035-5

Palacio, V. (1997). Identifying ecotourists in Belize through benefit segmentation: A preliminary analysis. Journal of sustainable tourism, 5(3), 234-243. https://doi.org/10.1080/09669589708667288

Pearce, P. L. (2005). Tourist behavior: Themes and conceptual schemes. Clevedon: Channel View. https://doi.org/10.21832/9781845410247

Rajapaksa, D., Gifford, R., Torgler, B., Garcia-Valiñas, M., Athukorala, W., Managi, S., \& Wilson, C. (2019). Do monetary and non-monetary incentives influence environmental attitudes and behavior? Evidence from an experimental analysis. Resources, Conservation and Recycling, 149, 168-176.

Ramkissoon, H., \& Mavondo, F. (2014). Proenvironmental behavior: The link between place attachment and place satisfaction. Tourism Analysis, 19(6), 673-688. https://doi.org/10.3727/108354214X14146846679286

Salam, M. A., Lindsay, G. R., \& BEVERIDGE, M. C. (2000). Eco-tourism to protect the reserve mangrove forest the Sundarbans and its flora and fauna. Anatolia, 11(1), 56-66.

Schaller, H., Jónasson, H. I., \& Aikoh, T. (2013). Managing conflicting attitudes: National parks in Iceland and Japan. TOURISMOS: An International Multidisciplinary Journal of Tourism, 8(2), 1-18.

Seers, S. B., \& Mair, J. (2009). Emerging green tourists in Australia: Their behaviors and attitudes. Tourism and Hospitality Research, 9(2), 109-119. https://doi.org/10.1057/thr.2009.5

Senaviratna, N. A. M. R., \& Cooray, T. M. J. A. (2019). Diagnosing multicollinearity of logistic regression model. Asian Journal of Probability and Statistics, 1-9. https://doi.org/10.9734/ajpas/2019/v5i230132

Steg, L., \& Vlek, C. (2009). Encouraging pro-environmental behavior: An integrative review and research agenda. Journal of Environmental Psychology, 29(3), 309-317. https://doi.org/10.1016/j.jenvp.2008.10.004

Tabachnick, B. G., \& Fidell, L. S. (2001). Using multivariate statistics (4th edn). New York: HarperCollins.

Tabernero, C., \& Hernández, B. (2011). Self-efficacy and intrinsic motivation guiding environmental behavior. Environment and Behavior, 43(5), 658-675. https://doi.org/10.1177/0013916510379759

Thapa, B., Graefe, A.R., \& Meyer, L.A. (2005). Moderator and mediator effects of scuba diving specialization on marine-based environmental knowledge-behavior contingency. The Journal of Environmental Education, 37(1), 53-67. https://doi.org/10.3200/JOEE.37.1.53-68

Tilden, F. (2009). Interpreting our heritage. University of North Carolina Press.

Tosun, C. (2001). Challenges of sustainable tourism development in the developing world: the case of Turkey. Tourism Management, 22(3), 289-303. https://doi.org/10.1016/S0261-5177(00)00060-1

Tung, T. (2013). Raising Awareness of Tourists for a Sustainable Tourism Development. Halong Bay Travel News Go Green, Responsible Travel, Retrieved from https://www.vspiritcruises.com/raising-awareness-of-touristsfor-a-sustainable-tourism-development/

Walker, K., \& Moscardo, G. (2014). Encouraging sustainability beyond the tourist experience: ecotourism, interpretation and values. Journal of Sustainable Tourism, 22(8), 1175-1196.

Wang, W., Wu, J., Wu, M. Y., \& Pearce, P. L. (2018). Shaping tourists' green behavior: The hosts' efforts at rural Chinese B\&Bs. Journal of Destination Marketing \& Management, 9, 194-203.

Witherspoon, S. (1994). The Greening of Britain: Romance and Rationality. In: Jowell, R., Curtis, J., Brook, L. \& Ahrendt, D. (Eds.), British Social Attitudes: the 11th Report (pp. 107-139). Dartmouth, Aldershot.

Wolf, C. (1993). Markets or governments: Choosing between imperfect alternatives. Mit Press.

World Tourism Organisation (WTO). (1989). Year Book of Tourism Statistics, Vol. 1, Madrid.

Wurzinger, S., \& Johansson, M. (2006). Environmental concern and knowledge of ecotourism among three groups of Swedish tourists. Journal of Travel Research, 45(2), 217-226. 


\section{APPENDIX A}

\begin{tabular}{|c|c|c|}
\hline \multicolumn{2}{|c|}{ Scale Items } & Sources \\
\hline \multicolumn{3}{|c|}{ Awareness Programs } \\
\hline 1. & Providing booklets, brochures or guide books & Wang et al. (2018); Lee \\
\hline 2. & Setting up public information or education centre & (2011); Bangladesh \\
\hline 3. & Attaching environmental signage indicating does and don'ts & Forest Department (2015); \\
\hline 4. & Telecasting or broadcasting the Sundarbans related program & Walker \& Moscardo (2014) \\
\hline 5. & Observing the Sundarbans day or arranging seminars & \\
\hline 6. & Showing a documentary films or arranging seminars & \\
\hline \multicolumn{3}{|c|}{ Incentivizing } \\
\hline 1. & Offering discounts on purchase of green foods or beverages & Line et al. (2017); \\
\hline 2. & Providing donation opportunities & Barber (2014); \\
\hline 3. & Awarding green tourist status for on-site green behaviour & Cheng et al. (2012); \\
\hline 4. & Offering sponsorship for organizing a green focused tour & Heyman \& Ariely (2004) \\
\hline 5. & Offering discounts on hotel booking while traveling during dull/ off se & \\
\hline \multicolumn{3}{|c|}{ Interpretations } \\
\hline 1. & Guiding the tourists with well-trained tour guides & Walker \& Moscardo (2014); \\
\hline 2. & Formal lectures/demonstration before entering the Jungle & Pearce (2005); \\
\hline 3. & Tour guide's instructions while walking in the Sundarbans & Wang et al. (2018) \\
\hline 4. & Informal discussion with the tour guide while traveling & \\
\hline 5. & Story telling by the tour guide while walking & \\
\hline \multicolumn{3}{|c|}{ Government Interventions } \\
\hline 1. & Providing environmentally friendly behaviour related info. & Bramwell \& \\
\hline 2. & Providing training to the tourists about green behaviour. & $(2001)$ \\
\hline 3. & Restricting the tourist from feeding the wild animals. & Gray et al. (2005); \\
\hline 4. & Restricting from disturbing the wild animals & Maycoo (2006); Bangladesh \\
\hline 5. & Restricting from taking photography using flash light & Forest Department (2015) \\
\hline 6. & Restricting tourists' movement in the protected areas. & \\
\hline 7. & Restricting from lighting the campfire or using sound system. & \\
\hline 8. & Imposing laws over the violation of the rules and regulation. & \\
\hline 9. & Imposing penalty for damaging the environment & \\
\hline 10. & Imposing penalty for wearing unacceptable dress or drinking alcohol. & \\
\hline
\end{tabular}

\section{Copyrights}

Copyright for this article is retained by the author(s), with first publication rights granted to the journal.

This is an open-access article distributed under the terms and conditions of the Creative Commons Attribution license (http://creativecommons.org/licenses/by/4.0/). 